\title{
Antituberculosis and Toxicity Assay of ethanolic extract of Mimba Cortex (Azadirachta indica JUSS.)
}

\author{
Cut Fatimah $^{1 *}$, ErfanWahyudi ${ }^{1}$, and Ernawati $\mathbf{B}^{2}$ \\ ${ }^{1}$ Universitas Tjut Nyak Dhien, Medan, Sumatera Utara, Indonesia \\ ${ }^{2}$ Local Health Laboratory, Sumatera Utara, Indonesia
}

\begin{abstract}
According to $\mathrm{WHO}$ has identified so much people with tuberculosis disorder, and includes a disease that causes death. Mycobacterium tuberculosis has been resistant to antituberculosis drugs were used, while the discovery of new synthetic antituberculosis are very slow. Traditionally, mimba cortex has been used to treat cough and bloody sputum. In previous research proved that the ethanol extract of mimba cortex can inhibit the in vitro growth of Mycobacterium tuberculosis. This study was conducted to determine the potential of mimba cortex as antituberculosis in vivo and toxicity test. Antituberculosis potency test in vivo in guinea pigs infected with Mycobacterium tuberculosis H37Rv directly into the bronchi using nebulizer. Then given mimba cortex extract 3 times a day $100 \mathrm{mg} / \mathrm{kgBW}$ and $50 \mathrm{mg} / \mathrm{kgBW}$. Isoniazid, Rifampicin and Ethambutol used as a comparison. Antituberculosis assessment examination conducted by Mycobacterium tuberculosis on bronchial fluid speciments were taken every two weeks and tested in culture with LowensteinJensen method. Acute toxicity test conducted on mice, the $\mathrm{LD}_{50}$ value calculation and observation of liver, kidney, and lung histopathology. The result of research showed that the ethanol extract of mimba cortex have antituberculosis activity in guinea pigs which has infected with Mycobacterium tuberculosis H37Rv, 3 times daily dosing of $100 \mathrm{mg} / \mathrm{kgBW}$ for 6 weeks, showed that bacterium from +3 to negative, and 3 times daily dosing of $50 \mathrm{mg} / \mathrm{kgBW}$ showed that bacterium from +3 to +1 . Acute toxicity test results showed $\mathrm{LD}_{50} \mathrm{I} \mathrm{I} .85 \pm 0.57 \mathrm{I}$. That is including mild toxic category.
\end{abstract}

Keywords : mimba cortex, antituberculosis activity, acute toxicity

\section{INTRODUCTION}

Tuberculosis (TB) is the infectious disease caused by the Mycobacterium tuberculosis which infect both latently or progressively and transmitted by human through cough and respiration mechanism. Mycobacterium tuberculosis is the acid resistant bacteria which have the spesific characteristic such as slow-rate growing but easily to become resistant. The slowrate growing character for this bacteria is one of the factor causing the development of antituberculosis is more difficult than the other antibacteria (Ganiswara, 1995).

Tuberculosis is the threat for Indonesia society. In 2004, there were increase in the new cases of tuberculosis as many as 250,000 cases, and 140,000 death each year. Most of the tuberculosis patient are the productive age group aged 15-55 years old. This disease is the third deathly disease after cardiovascular disease and accute respirational disease in all age (Depkes RI, 2005).

The increase of the tuberculosis patient number is caused by some factors one of them is the uncompliance in the drugs therapy by the patient. The other factors are the high price of the drugs, multiple drug resistance, lack of hospes immunity against micobacteria, reduction in bactericidal power of the drugs, and patient economy crisis (Depkes RI, 2005).

The drugs commonly used in the tuberculosis therapy are isoniazid, pirazinamid, rifampisin, ethambutol, and streptomycin. Most of the tuberculosis patient could be cure by those drugs, but the resistance phenomenon makes another choice for drugs therapy is needed (Wattimena, et al., 1991).

Traditionally, mimba herbs (Azadiracta indica Juss) is used as the cure for some diseases, such as pertussis and cough up blood (Dalimata, 1999). Numerous studies have reported that mimba seeds can inhibit the growth of Salmonella thyposa, Streptococcusaureus (Ambarwati, 2007), Streptococcus mutant and Streptococcus faecalis (Almas, 1999).

\footnotetext{
*Corresponding author e-mail: cutmah57@gmail.com
} 
Mimba oils can also inhibit the growth of $E$. coli and Kleibsiella pneumonia (Sai Ram, et al., 2000) besides, the etanolic extract of mimbacortex can inhibit the growth of Mycobacterium tuberculosis (Fatimah, 2012).

Based on its empirical use property and the previous studies, mimba herbs have the potency as a natural antituberculosis agent. In this study, we determined the antituberculosis activity of ethanolic extract of mimba cortex (EEM) by in vivo assay using Mycobacterium tuberculosis H37RV infected marmot, and its toxicity using mice. The result of this research showed that mimba cortex potential to be developed as the alternative drugs of tuberculosis treatment.

\section{MATERIALS AND METHODS}

\section{Plants Extraction}

Mimba cortex was dried and powdered, thenphytochemistry screening and quality test of simplisia was done. Extraction by percolation then conducted using $80 \%$ ethanol.

\section{Antituberculosis Activity Assay}

Antituberculosis activity of ethanolic extraxt of mimba cortex was determined using infected marmot. Marmot was spread using $3 \mathrm{~mL}$ suspension of Mycobacterium tuberculosis H37RV (from CV. Varka Bayak Medan) directly on bronchus by using nebulizer every 24 hours during 7 days respectively, continued with once every 2 days during 7 days and once every 3 days during 7 days. The spread of $20 \mathrm{~mL}$ aquadest was taken from esophagus. Identification and cultivation of Mycobacterium tuberculosis was done on $\mathrm{LJ}$ medium. The positive tuberculosis marmot then devided in 5 groups. Group 1: EEM $100 \mathrm{mg} / \mathrm{kg}$ BW, three times a day. Group 2: EEM $50 \mathrm{mg} / \mathrm{kg}$ BW, three times a day. Group 3: isoniazid control. Group 4: etambutol control. Group 5: rifampisin control. After administrated with each treatment, specimen sampling was done each week for 4-5 samplings. Specimens were placed in test tube then homogenized with phosphate buffer $\mathrm{pH} 7$ and inoculated into two test tubes contain with $\mathrm{LJ}$ medium. Inoculums were incubated in $37^{\circ} \mathrm{C}$ for 6 8 weeks and the growth were observed with criteria:

(-) : no growth

(+1) : medium covered with slight colony, $1-$ 200 colonies

(+2) $\quad: 1 \frac{1}{2}$ of medium surface covered with yellow colony, $200-500$ colonies

$(+3) \quad: 3 / 4$ of medium surface covered with yellow colony, $500-2000$ colonies
(+4) : all of medium surface covered with yellow colony >2000 colonies (Japan Intternational Coorperation Agency, 1987).

\section{Toxicity Assay}

EEM was suspended in CMC-Na solution within $50 \%$ concentration.Toxicology assay was performed on 30 male mices (2-3 months), weighed from 20-30 grams, and were acclimatized for 7 days. Mices were devided 5 each treatments (WHO, 1993). Control treatment: CMC-Na control; treatment 1: EEM dose I; treatment 2: EEM dose II; treatment 3: EEM dose III; treatment 4: EEM dose IV and treatment 5: EEM dose V.

Toxicity assay was conducted in 3 stage of dose determination: dose orientation test, preliminary test, and actual test. $\mathrm{LD}_{50}$ was determined using Thompson Weil method in multilevel dose consists of 5 doses variant. Physical observation of toxic symptom was conducted intensively during 24 hours to all groups of mices. Observation was continued within 14 days. The number of dead mice in each group was scored then the $\mathrm{LD}_{50}$ range was determined according to the following formula:

$$
\mathrm{LD}_{50} \text { range }=\operatorname{antilog}(\log \mathrm{m} \pm 2 \times \delta \log \mathrm{m})
$$

$$
\begin{aligned}
& \text { Annotation: } \\
& \mathrm{m}=\mathrm{LD}_{50} \\
& \mathrm{D}=\text { smallest dose } \\
& \mathrm{d}=\text { multiple dose log } \\
& \mathrm{f}=\text { Weil factor }
\end{aligned}
$$

Liver, kidney and lung was removed then immediately washed by aquadest and soaked in formaline buffer $10 \%$ to perform the histopatology assay.

\section{RESULTS AND DISCUSSIONS}

\section{The Antituberculosis Activity of EEM}

Antituberculosis activity assay was performed to 5 groups as explained in method section. The result indicates that there is an inhibition of bacterium growth. The number of bacterium before treatment is +3 (based on Japan International Coorperation Agency criteria). There is reduction from +3 to $\mathrm{TB}$ negative in control group at the third week of spacimen sampling. The reduction of bacterium number from +3 to negative TB in group 1 occurs at the fourth week of specimen sampling.

Group 2 shows the reduction of bacterium number from +3 to +1 at the fourth week of specimen sampling. 


\section{EEM Toxicity Assay}

First stage of test performed as orientation test to determine the dose administrated to the next stage of test. Mice were administrated with two multiple dose escalation of EEM and then observed during 24 hours until there is a death of mice. The result of this first test shows $20 \%$ death of group 4 which administrated with EEM dose 80 $\mathrm{mg} / 20 \mathrm{~g} \mathrm{BW}$.

According to this orientation test result, preliminary test can be continued using the smallest dose of the orientation test. The preliminary test was conducted using EEM dose $50 \mathrm{mg} / 20 \mathrm{~g} \mathrm{BW}$, the dose approaching $20 \%$ death dose, because there was no death after $40 \mathrm{mg} / 20 \mathrm{~g}$ BW dose administration. Dose then increased to be $100 \mathrm{mg} / 20 \mathrm{~g} \mathrm{BW}$ then observed during 24 hours. The result shows $0 \%$ death of group 1 and group 2 . Based on the result, the actual test can be continued using the dose caused $0 \%$ death, 100 $\mathrm{mg} / 20 \mathrm{~g} \mathrm{BW}$.

The assay then continued with minimal dose $100 \mathrm{mg} / 20 \mathrm{~g} \mathrm{BW}$. The dose multification were increased based on the calculation below:

$\mathrm{R}=1.4142$

$\mathrm{R}=$ antilog $\mathrm{d}$

$\mathrm{d}=\frac{\log \text { dose multification }}{\text { total animal number of group } 1}$

The calculation for dose multification between the groups and group 4 is 4 , thus:

$\mathrm{d}=\frac{\log 4}{4}$

$\mathrm{d}=\frac{0.602}{4}=0.15051$

$\mathrm{R}=\operatorname{antilog} 0.15051=1.4142$

The treatment were done for 14 days. Based on the assay, some male mice were dead by the single dose treatment in several dose of treatment. The $\mathrm{LD}_{50}$ value were calculated with
Thompson well equation and the $\mathrm{LD}_{50}$ value is $11.85 \mathrm{mg} / \mathrm{kg} \mathrm{BW}$ per oral. The equation is stated below:

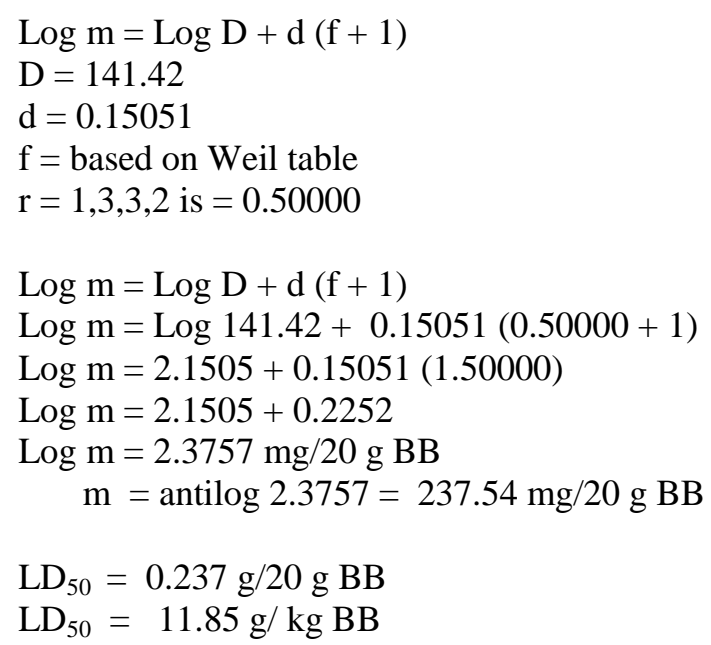

Then the $\mathrm{LD}_{50}$ range value was calculated. The $\mathrm{LD}_{50}$ range value is $(11.85 \pm 0.571) \mathrm{mg} / \mathrm{kg}$ BW.

$\mathrm{LD}_{50}$ range value $=\operatorname{antilog}(\log \mathrm{m} \pm 2 \times \delta \log \mathrm{m})$ $\delta \mathrm{f}=$ based on Weil table

$\mathrm{r}=1,3,3,2=1.90394$

$\mathrm{d}=0.150151$

$\mathrm{m}=\mathrm{LD}_{50}$ value $=0.237 \mathrm{~g} / 20 \mathrm{~g} \mathrm{BW}$

$\delta \log \mathrm{m}=0.150151 \times 1.90394$

$\delta \log \mathrm{m}=0.28587$

$\mathrm{LD}_{50}$ range value $=$ antilog $(\log \mathrm{m} \pm 2 \times \delta \log \mathrm{m})$

$$
\begin{aligned}
& =0.237 \pm 2 \times 0.28587 \\
& =(0.237 \pm 0.57175) \mathrm{g} / 20 \mathrm{~g} \mathrm{BW} \\
& =(11.85 \pm 0.57) \mathrm{g} / \mathrm{kg} \mathrm{BW}
\end{aligned}
$$

Based on the $\mathrm{LD}_{50}$ range values shows that EEM classified in slightly toxic. The toxicity criteria of EEM single dose was determined using Frank C. Lu, (1995) criteria according to the following table:

Table I. Toxicity criteria based on the LD $_{50}$ range values

\begin{tabular}{ll}
\hline Criteria & LD50 range values \\
\hline Super toxic & $\leq 5 \mathrm{mg} / \mathrm{kgBB}$ \\
Highly toxic & $5-50 \mathrm{mg} / \mathrm{kgBB}$ \\
Very toxic & $50-500 \mathrm{mg} / \mathrm{kgBB}$ \\
Moderately toxic & $0.5-5 \mathrm{~g} / \mathrm{kgBB}$ \\
Slightly toxic & $\leq 15 \mathrm{~g} / \mathrm{kgBB}$ \\
Non toxic & $>15 \mathrm{~g} / \mathrm{kgBB}$ \\
\hline
\end{tabular}




\section{Histopatology Analysis}

Histopatology interpretation shows that there is damage in liver, kidney and lung on each treatment groups and control group. Liver and kidney histopatology analysis can be performed with random observation in some field of view.

The damage level of liver is increased from group 1, group 2, group 3, group 4 to group 5 respectively. It shows that the EEM dose excalation can increase toxicity on mice liver.

Histopatology analysis shows the necrosis on kidney according to proximal tubule constriction around glomerular. Control group shows 5\% damage and the percent damage increases regarding to the dose level. The damage level of kidney is increased from group 1, group 2, group 3, group 4 to group 5 respectively. Group 5 shows $20 \%$ damage on kidney and gives the most severe damage compare with the other groups. It means that the excalation of EEM dose level can increase toxicity in mice kidney.

The result shows that EEM administration to mices in 14 days of observation period causes the liver and kidney damage on mice (Musmusculus Linn). EEM gives the toxic activity in dose dependent manner. The necrosis of liver was predicted caused by the active compound of EEM. Mimba herbs contain several active compound such as azadirachtin, salanin, meliantriole, nimbin, nimbolidedangedunin (Biswas, et al, 2002).

\section{CONCLUSION}

EEM can treat tuberculosis marmot infected with Myobacterium tuberculosis H37RV at the certain dose and is classified in slightly toxic.

\section{AKNOWLEDGEMENT}

We express our gratitude to DP2M Dirjen DIKTI, Chief of Balai Pengobatan Penyakit Paru
Sumatera Utara, Nur Sabrina and Bagekin, and Faculty of Pharmacy UTND Medan.

\section{REFERENCES}

Almas, K., 1999, The Antimicrobial Effects of extracts of Azadirachta indica (Neem) and Salvadora persica (Arak) Chewing Sticks, Indian J. Dent. Res., I O(I), 23-6.

Ambarwati, 2007, The Effectiveness of Antibacteria Substances from Neem Seeds (Azadirachta Indica) to Impede the Growth of Salmonella Thyposa and Staphylococcus Aureus, Biodiversitas, 8(3), 320-325.

Anonim, 2000, Pedoman Pelaksanaan Uji Klinik Obat Tradisional, Departemen Kesehatan RI, Jakarta.

Biswas, K., CHattopadhay, I., Bnerjee, R.K. and Bandyopadhyay, U. 2002, Biological Activities and Medicinal Properties of Neem (Azadirachta Indica), Curr. Scie., 82(II), I336-I 345.

Dalimatha, S., 2000, Atlas Tanaman Obat Indonesia, Jakarta: Trubus Agriwidya.

Depkes RI, 1995, Materia Medika Indonesia, Jilid IV, Jakarta: Departemen Kesehatan Republik Indonesia.

Depkes RI, 2000, Parameter Standar Umum Ekstrak Tumbuhan Obat, Jakarta: Departemen Kesehatan Republik Indonesia.

Fatimah, 2012, Uji Aktivitas Antituberkulosis Ekstrak Etanol Kulit Batang Mimba (Azadirachta indika Juss.) terhadap Mycobacterium tuberculosis, Universitas Tjut Nyak Dhien Medan, Sumatera Utara.

Ganiswara, 1995, Farmakologi dan terapi, Jakarta: Gaya Baru, 602-603.

Wattimena, J.R., 1991, Farmakodinamik dan Terapi Antibiotik, Yogyakarta: GadjahMada University Press. 